\title{
The Effect of Financial Performance in Commercial Banks in Nigeria
}

\author{
Achaka Samuel Achaka* ${ }^{*}$ Edoh Akare Moses, Christopher N. Jatau, Dr. Ado \\ Department of Accounting and Finance, Faculty of Management Science, Abubakar Tafawa Balewa University, Bauchi, Bauchi State, Nigeria
}

DOI: 1 10.36348/sb.2019.v05i12.010 $\quad$ | Received: 30.11.2019| Accepted: 07.12.2019| Published: 20.12 .2019

*Corresponding author: Achaka Samuel Achaka

Abstract

The Nigerian Banking Industry is expressing a revolution as a result of innovations in technology that has become a common feature of the banking sector amongst other contemporary business environment. The arrival of the Internet and the advancement of mobile telecommunication companies in Nigeria present both an opportunity and a challenge to banks in Nigeria. The test for the banking sector has been how to profitably formulate a new service delivery means in such a way that its clients will curiously learn to use and trust. The purpose of this work is to identify the effect of bank creativity on the financial performance of commercial banks in terms of their income or revenue generation, liquidity, efficiency, profitability and the general patronage of banking services in Nigeria. Questionnaires were administered to find out the opinions of bank executives on the effect of bank innovations on financial performance. It was discovered that most of the innovations have positive effect on the income generating potentials of the banks, they also improves efficiency, liquidity and profitability of the banks. It is recommended that corporate banks must make it a policy to establish an efficient and effective marketing department to oversee the publicity of all bank innovative products. Government through the Central Bank of Nigeria (CBN) must continue researching into innovations in the financial sector. Bank

Keywords: Financial Performance, Commercial Banks, liquidity, efficiency.

Copyright @ 2019: This is an open-access article distributed under the terms of the Creative Commons Attribution license which permits unrestricted use, distribution, and reproduction in any medium for non-commercial use (NonCommercial, or CC-BY-NC) provided the original author and source are credited.

\section{INTRODUCTION}

This study is to determine how financial innovative products affect the financial performance of the Nigeria's Banking Sector. Rose [1] defines banks as any financial institutions which offer a broad range of financial services, including the provision of credits, deposits and payment systems, employing an extensive variety of financial intermediation functions in any business economy. According to Lerner and Tufano [2], financial innovation is defined as the act of creating and then popularizing new financial assets or products, as well as new financial technologies, organizations and markets $^{\text {ee }}$. In recent past, it was possible for banks to satisfy their customers and to meet their own performance targets without the need to develop any new products to enhance service delivery due to the fact that account holders and banks were few, with the low volume of transactions, and luck of competition in the banking industry. According to the 2014, Ghana Banking survey by PricewaterhouseCoopers, Ghana has 27 universal banks, 137 rural and community banks, 58 non-bank financial organizations including, leasing firms, mortgage providers, finance houses, and saving and loan institutionse. These do not include the hundreds of," Susu ce collectors, who serve as informal, small-scale depository financial organizations for market sellers, artisans and commercial transport operators. Of the twenty-seven (27) universal banks, 10 are owned by Ghanaians while the remaining is backed by international owners. Bank innovations involve the development of new products/services or production process that lead to efficient and effective operations. Nofie [3], described innovations in the banking industry as the entrance of new or improved products or processes which reduces the operational cost of rendering existing banking services. According to Agboola [4], the adoption of Information and Communication Technology in financial institutions have improved customer services, facilitated the accuracy of account, provided for home and office banking services, ensured convenient business hours, timely and fair attention, and improved service delivery. The liberalization of banking industry by the Central Bank of Nigeria, and the resultant rise in competition among the banking and non-banking financial institutions in the Nigerian financial market has brought to the fore the need for the creation of innovative financial assets or products that would maintain current 
customers and attract new ones. 2. Statement of the Problem The traditional commercial banking is declining in terms of competition and this may threaten the financial stability of the banks. Therefore, banks in Nigeria must have business strategy that include the development, implementation and evaluation of the effect of innovative products, aimed at maintaining existing customers and attracting new ones, such innovations must also improve efficiency and profitability of the banks. Banks in Nigeria have been generally slow in adopting new and modern innovative ways of improving service delivery to their customers, and three reasons may be attributable to their lackadaisical attitude toward the development of new financial innovations. Firstly, the payback period for the initial capital outlay may be longer and unacceptable to management and shareholders, secondly, these innovations may not have a positive correlation with financial performance in terms of efficiency and profitability and thirdly, the innovations may, nevertheless have their peculiar problems like computer and internet frauds, frequent breakdowns of the system and lack of personnel with requisite skill and commitment, which the banks needed in order to satisfy their customers, stay in business and effectively compete. 3. Objective of the Study The general objective of this work is to identify the effect of bank innovations on the financial performance of the commercial banks in Nigeria. Specific objectives includes: 1. To examine the effect of innovations on liquidity and efficiency of commercial banks in Nigeria. 2. To examine the effect of bank innovations on the levels of profits of the universal banking institutions in Ghana. 3. To find out the effect of bank innovations on patronage of banking services.

\section{RESEARCH QUESTIONS}

With regard to the research objectives the following sampled questions adapted from previous studies by Ngumi [5] were posed to management, heads of departments and staff of selected commercial banks in Nigeria:

1. Whether Automatic Teller Machines (ATMs) have had an encouraging impact of improving bank earnings in terms of commissions?

2. Whether ATMs control the reduction of costs, and thereby resulting in improved return on assets for the bank?

3. Whether Mobile/Internet Banking achieves less costs of operation resulting in greater amounts of profits over their useful life to the firm?

4. Whether Mobile/Internet Banking facilitates or enhances the accessibility to funds by customers for ease of withdrawal?

\section{Literature Review 2.1}

Financial performance of commercial banks

Creativity and innovations are crucial for the survival of every business whether in the private or public sector. According to Damanpour et al. [6], innovation affects a firm's performance positivelyee. Frimpong [7] states that "innovations provide an impetus for banks to improve their market performance by recovering from palpable inefficiencies prevalent in the banking industry, as is the case in Nigeria and other emerging countries". Profitability and efficiency are the major motives for banks to assume risks for expansion in its operations. Some of the measures that are used in evaluating bank's profitability and efficiency are Return on Asset, Return on Equity, Net Profit Margin. Bank innovations have the potentials to increase the volume of retail transactions through increased usage of electronic transfers and payment systems which encourage the banking business. According to Mawutor [8], "The introduction of E-banking has indeed had a positive effect on the profitability of Agricultural Development Bank (ADB) since it was introduced”.

\section{Bank innovations and customer deposits}

According to Domeher et al. [9], "the ease with which customers can use the innovation, the compatibility of the innovation with customers ${ }^{\text {ee }}$ needs, the perceived usefulness thereof, the amount of information provided on the innovation and the level of customers" education all have a significant positive impact on the adoption of e-banking innovations in the Nigerian banking industryee.

\section{Types of bank innovation products Internet banking}

Internet banking involves the conduct of conventional banking activities on the Internet, that is, the global network of computer which does not depend on any "brick and mortar" office building; it offers financial services that are accessed through the Internet's World Wide Web (W.W.W.). By reducing the overhead expenses of traditional banks, Internet banks in theory can offer clients better interest rates on deposits than that of traditional banking average rate. Banks often rely on the Internet to convey information about financial products to the general public, replace business conducted at the branch offices, which do away with the need to put up new branches, and to serve clients more efficiently. Internet banking sites present the prospect of more suitable means to manage customer finances, and such activities as paying bills on-line, searching for mortgage or auto loans, applying for credit cards.

\section{Branch networking}

Networking of bank branches is the computerization and inter-connecting of geographically scattered unconnected bank branches, into one integrated system in the form of a Wide Area Network (WAN) or Enterprise Network (EN) for creating and sharing of consolidated customer information or records. The advantage is that it present is faster rate of inter-bank dealings as the problem of remoteness and 
time constrains are removed. Thus, there is extra output per time period. There are a number of networked branches serving the customer at different locations of convenience to the client. There is virtual division of labour between bank branches by means of its connected positive effect on output among the branches. Additionally, as it reduces customer journey distance to their home bank branch, it makes extra time available for the clients ${ }^{\text {ee }}$ productive activities.

\section{Electronic fund transfer at point of sale (eftpos)}

An EFTPOS is an on-line arrangement that enables clients to transfer funds directly from their bank accounts to a merchant ${ }^{\text {ee }} \mathrm{s}$ accounts after making purchases (at purchase points). An EFTPOS employ a debit card to start an electronic fund transfer process [10], improved banking efficiency resulting from the use of EFTPOS to service clients shopping payment conditions as an alternative to the bookkeeping duties in handling cheques and cash withdrawals for purchases. Also, the system remained operational even after regular banking hours; therefore, the bank continues to achieve efficiency even after normal banking hours. It also saves clients time and energy in travelling to branches or ATMs for cash withdrawals which can be exploited into other productive services.

\section{Cash smart cards}

Smart cards are implanted with microchip that enables data to be stored on the card. These cards are referred to as Stored Value Cards. Its application is to store the customer's account information, identification and value of his account and electronically transfer the customer's account. It has the advantage of carrying cash without the risk of having the cash lost or stolen. The smart card gives the customer the convenience to cash money even after normal banking hours and can be spent and loaded easily. It also gives the bank, the ability to control the secure communication or transaction information between itself and its customer. However, if a criminal manages is to find the pass code of a customer, he can access his account hence putting both the bank and the customer at risk.

\section{RESEARCH METHODOLOGY}

This section deals with the methodology employed in carrying out this study. The chapter carefully examined the data sources and techniques used for data analysis. It also focuses on the methodology by which information was collected, analyzed and interpreted. The research was based on intuitive, authoritative knowledge, reasoning from findings and empirical evidence from demons ratable facts through observation and or experimentation data collection and analysis. The methodology covers the research design, population and sample size, sampling techniques, data collection and analysis, reliability and validity of data and ethical consideration.

\section{RESEARCH DESIGN}

According to Polit et al. [4], "a research design is the overall plan for obtaining answers to the questions being studied and for handling some of the difficulties encountered during the research process". In effect, the research design is the plan or process that collects data to answer the research questions posed. This study used the survey methodology. According to Nesbary [12], a survey research is a process of collecting representative sample data from a larger population and using the sample to infer attributes of the population ${ }^{\text {ee }}$. The justification for using this design is that it allows for the generalization of results from sample perspective for the whole population.

\section{Population of the study}

The target population for this study is management, senior staff and heads of sections or departments of selected commercial banks in Nigeria.

\section{Banking sector experience of respondents}

The following were the result obtained from the study with regard to experiences of respondents in the banking industry. Table 4.1.4 Experience of Participants Period Number Percent $(\%)$. Less than 1 year 22 between $1-5$ years 2018 between $5-10$ years 3229 Over 10 years 5651 Total 110100 Source: Field Data, 2019. The experiences of the participants examined showed that, the greater amount of the participants were in the years' bracket of over 50 years representing $51 \%$. This was followed by participants between 5 - 10 years who accounted for $29 \%$ of the sampled size; the next bracket is $1-5$ with 18 percentage point, with the least percentage point participants with less than 1 year. Most of the bank executives have being working for more than five years which shows that staff retention in the banking sector is significant as it is generally assumed that, the more the worker stays on a job for a long time, the more efficient and effective he/she becomes in terms of performance of output and the ultimate ripple effect on the banking sector in general.

\section{DATA ANALYSIS OF BANK INNOVATIONS Effect of bank innovations on total revenue}

The aim of this section is to find out the effect or influence of bank innovations on revenue of commercial banks in Nigeria. The questionnaire was framed in the form of a statement made for the respondents to confirm the degree of their agreement or otherwise. The likert scale was used to assign values to the responses.

\section{Automated teller machines (atms)}

Analysis of data collected on the effect of ATMs on increasing commission, interest income and the potential for generating income for the banks are presented in table 4.2.1.1. Which shows that $83 \%$ 
representing about 91 of the respondents agreed in total that ATMs have positively affected fee based income, $15 \%$ were neutral and $2 \%$ are in disagreement. In the same vein, when asked about ATMs influence on interest based income $23 \%$ of respondents totally agreed, $4 \%$ were indifferent and $73 \%$ totally disagreed that ATMs affect interest income. $72 \%$ of the respondents totally agreed that ATMs have the potential to expand income generating capabilities of the banks.

\section{FINDINGS, CONCLUSION AND RECOMMENDATIONS INTRODUCTION}

This study sought to find out the effect of bank innovations on the financial performance of commercial banks in Nigeria. There are so many innovations in the financial sector, but this investigation was limited to Automated Teller Machines (ATMs) and Mobile/Internet Banking. The study throw light on the consequences of these innovations that the banks are coming up with on total income, return on assets, patronage of bank services in Nigeria and profitability of the banks.

\section{SUMMARY OF FINDINGS}

The arrival of the Internet and the proliferation of mobile telecommunication companies in the Nigerian economy have offered both an opportunity and a test for the Nigerian banking sector. For years, commercial banks in Nigeria have used strong computer networks to mechanize millions of daily transactions, but in recent times, frequently the only paper record is the customer's receipt at the ATMs or point of sale. Now that bank customers can be linked to the internet through personal computers and mobile phones, banks foresee related economic benefits by adapting new and innovative electronic processes for their operations. Various findings were made with respect to the three stated objective as follows: The first objective was to ascertain the impact of bank innovations on revenue of commercial banks in Nigeria. It was discovered that most of the innovations have positive effect on income. For example, $83 \%$ of the bank executives interviewed agreed that ATMs have great influence on income, again $79 \%$ of those interviewed agreed that mobile banking increased incomes of the banks, this is indicative for the fact that management will easily be

\section{CONCLUSION}

The purpose of this work was to identify the effect of bank innovations on the financial performance of commercial banks in terms of income generation, liquidity, efficiency, profitability and the general patronage of banking services by Nigerians. This work is a survey of bank executives from fifteen (15) commercial banks in Nigeria by the use of questionnaires that were administered to find out opinions of bank executives on the effect of bank innovations on financial performance. From this study it was found that the performance of banks in Nigeria in the near future would greatly be based on factors such as the introduction of efficient and effective innovative products such as ATMs and Mobile/Internet banking to attract customers, who are seeking for ease of banking, "presence everywhere banking", better customer service, and a convincing image of a strong bank. These innovative products have the potential to improve upon the revenue generation and profitability of the universal banks. The arrival of the Internet and mobile telecommunication companies in Nigeria present both an opportunity and a challenge to banks in Nigeria. The test for the banking sector has been how to formulate a new service delivery means in such a way that its clients will enthusiastically learn to use and rely on. After all, banks have spent many years to achieve customer's trust, and they are not prepared to risk that on an internet site that is wearisome, confusing and less secure. Most of the commercial banks now present completely secure and functional online banking for free or for a small fee to the customers. The opportunities presented could be seen in the area of operational cost reduction that could be achieved through these innovative products, increase in customer base or patronage of banking services. 5.4 RECOMMENDATIONS From this study it has become clear that by embarking on e-banking and other banking innovation of commercial banks in Nigeria will consolidate their gains and assets base by becoming

\section{REFENCES}

1. Rose, N. (1999). Powers of freedom: Reframing political thought. Cambridge university press.

2. Lerner, J., \& Tufano, P. (2011). The consequences of financial innovation: a counterfactual research agenda. Annu. Rev. Financ. Econ., 3(1), 41-85.

3. Nofie, I. (2011). The diffusion of electronic banking in Indonesia. Manchester Business School.

4. Agboola, A.A. (2003). Information Technology, bank automation, and attitude of works in Nigerian banksee. Journal of Social Sciences.

5. Gakure, R., \& Ngumi, P. (2013). Do bank innovations influence profitability of commercial banks in Kenya. Prime journal of social science, 2(3), 237-248.

6. House Coopers, P. W. (2008). Raising the bar: increase in the minimum capital requirements, and implications for the Industry. Ghana Banking Survey, Accra, available at: www. pwc. com/gh (accessed January 2, 2015).

7. Frimpong, J. M. (2010). Investigating efficiency of Ghana banks: A non-parametric approach. American Journal of Scientific Research, 7(4), 64-76.

8. Ghana Banking Survey. (2014). The Future of Banking in Ghana... Whates next?"e. Price Waterhouse Coopers, Accra. Innovation types and organizational 
Achaka Samuel Achaka et al., Sch Bull, Dec 2019; 5(12): 762-766

performance: A longitudinal study of service.

9. Domeher, D., Frempong, J. M., \& Appiah, T. (2014). Adoption of financial innovation in the Ghanaian banking industry.
10. Chorafas, D. N., Chorafas, D. N., Chorafas, D. N., \& Chorafas, D. N. (1988). Electronic funds transfer (p. 142). Butterworths.

11. Nesbary, D. (2000). The taxation of Internet commerce. Social Science Computer Review, 18(1), 17-39. 